\title{
Determination of Vitamin A and its Metabolites in Rat Testis: Possible Involvement of Vitamin A in Testicular Toxicity Caused by Molinate
}

\author{
Fabiola G. Zuno-Floriano • Dirk Holstege • \\ Matt J. Hengel • Nilesh W. Gaikwad • \\ Maria L. Aldana-Madrid • Marion G. Miller
}

Received: 5 December 2011 / Accepted: 17 March 2012/Published online: 29 March 2012

(c) The Author(s) 2012. This article is published with open access at Springerlink.com

\begin{abstract}
This study was conducted to evaluate the effect of molinate on retinoids homeostasis in rat testis. Molinate was administrated to male Sprague-Dawley rats (200 $\mathrm{mg} \mathrm{kg}^{-1}$ in corn oil, ip). Retinoid measurements were made at $6,12,48$ and $168 \mathrm{~h}$ time points after administration. Testis levels of retinoic acid decreased (32\%) in a statistically significant manner at the 12 and $48 \mathrm{~h}$ time points. However, retinol and retinaldehyde were not significantly affected by molinate. These results suggest that molinate affects retinoic acid synthesis in testis and could contribute to understanding the molecular mechanism of molinate involved testicular toxicity.
\end{abstract}

Keywords Molinate - Retinoids - Retinoic acid .

Testicular-toxicity

Molinate, a thiocarbamate herbicide used in rice culture, has been shown to be a testicular toxicant in rats (Ellis et al. 1998; Jewell and Miller 1998). However, molinate toxicity is not clear. Previous studies have shown that there are two main routes by which molinate is metabolized: hydroxylation of the ring and oxidation of the thiol moiety (DeBau et al. 1978; Wilkes et al. 1993; Allen et al. 2010). Several reports have shown the toxicological effect of molinate and

F. G. Zuno-Floriano $(\bowtie) \cdot$ D. Holstege

M. J. Hengel · N. W. Gaikwad · M. G. Miller

Department of Environmental Toxicology,

University of California-Davis, One Shields Avenue,

Davis, CA 95616, USA

e-mail: fgzuno@ucdavis.edu

M. L. Aldana-Madrid

Departamento de Investigación y Posgrado en Alimentos,

Universidad de Sonora, Hermosillo, Sonora, Mexico its metabolites in rat testis. Ellis et al. (1998) reported that male rats treated with molinate showed sperm lesion at a dose of $140 \mathrm{mg} \mathrm{kg}^{-1}$ day for 7 days. Molinate also, inhibits retinaldehyde dehydrogenase (RALDH) and inhibits RALDH-catalyzed metabolism of retinaldehyde to retinoic acid (Hart and Faiman 1995). Retinoic acid has an important role in reproduction where it plays a critical role in spermatogenesis (Chung and Wolgemuth 2004). Retinoic acid strongly stimulates the proliferative activity of A spermatogonia, the least differentiated germ cell in the testis (Gaemers et at. 1996).

In order to explore an alternative mechanism by which molinate could produce testicular toxicity, an in vivo study with Sprague-Dawley rats was conducted to determine the effect of molinate on retinoid homeostasis in testis. Retinoid levels in testis were measured at various times after molinate exposure at a dose where testicular damage is manifested (200 $\mathrm{mg} \mathrm{kg}^{-1}$ ) (Jewell et al. 1998).

\section{Materials and Methods}

All solvents were HPLC grade and were obtained from either Fisher Scientific (USA) or Sigma-Aldrich (USA). $O$-Ethylhydroxylamine and retinoid standards were from Sigma-Aldrich (USA). Molinate (99\% purity) was from Chem Service (West Chester, PA, USA). Corn oil was food grade and obtained locally. The water (resistivity 18.2 megahohm-cm) used was produce in-house using a Milli-Q water system.

Male Sprague-Dawley rats were purchased from Charles River (Hollister, CA, USA). The animals were obtained at 80-90 days of age and were housed under strictly controlled conditions (temperature $22^{\circ} \mathrm{C}$, humidity $50 \% \pm 10 \%$ ) under $12 \mathrm{~h}$-light/12-h dark cycle for a least 
1 week prior to use. Animals were fed with Purina rat chow 5012 containing $12 \mathrm{IU}$ vitamin $\mathrm{A} / \mathrm{g}$. In the time-course study to determine molinate's effects in testicular retinoid homeostasis, four rats in each treatment group were given by intraperitoneal injections at a dose of $200 \mathrm{mg} \mathrm{kg}^{-1}$ of molinate $\left(1.5 \mathrm{ml}\right.$ corn oil $\left.\mathrm{kg}^{-1}\right)$. Animals were euthanized by carbon dioxide asphyxiation in accordance with AVMA guidelines. Testes were collected at 6, 12, 48 and $168 \mathrm{~h}$ after administration of molinate. Controls animals were used at all-time points. The animal protocol was approved by AAALAC accredited (000029) and PHS assured (A3433-01) facility under protocol number 12944. The rat testes were removed and homogenized immediately. Prior to homogenization, $4 \mathrm{ml}$ of PBS ( $\mathrm{pH} 7.4,0.1 \mathrm{M}$ ) per gram of sample were added per gram of tissue. For each assay, testes were homogenized on ice at $280 \mathrm{rpm}$ using a motorized homogenizer (Black \& Decker, model 2Z040, Chicago, IL, USA). Retinoid were extracted from the sample homogenate based on a method by Kane et al. (2005, 2008a, b). The retinaldehyde were prepared by using $O$-ethylhydroxylamine to convert the reactive aldehyde group to a stable $O$-ethyl oxime derivative. Retinoid standard concentrations were verified spectrophotometrically using molar extinction coefficients (Baura and Furr 1998). Quantitation of retinol, retinal-oxime, and retinoic acid was performed on a Sciex API 2000 triple-quadrupole MS system (Perkin-Elmer, Shelton, CT) controlled by Analyst 1.3.1 software (Applied Biosystems, Foster City, CA). The retinoid were separated using C18 Allure column $(50 \times 3.2 \mathrm{~mm}$ i.d., $5 \mu \mathrm{m}$ particle size, Restek, Bellefonte, PA, USA) with a C18 guard column $(4 \times 3.0 \mathrm{~mm}$ i.d., Phenomenex, Torrance, CA, USA). Injection volume was $20 \mu \mathrm{L}$. The HPLC was operated at a flow rate of $750 \mu \mathrm{L}$ $\min ^{-1}$ using a program consisting of $40 \%$ water $/ 60 \%$ acetonitrile $/ 0.1 \%$ formic acid for $0.5 \mathrm{~min}$, followed by $8 \%$ water $/ 92 \%$ acetonitrile $/ 0.1 \%$ formic acid over $1.5 \mathrm{~min}$, followed by a linear gradient to $100 \%$ acetonitrile over $2 \mathrm{~min}$ and then held at $100 \%$ acetonitrile for $6.5 \mathrm{~min}$.

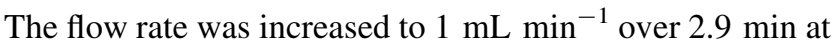
$10.7 \mathrm{~min}$. The total run time was $13.5 \mathrm{~min}$. The retention times observed for retinol, retinal-oxime and retinoic acid were $6.03,8.67$ and $6.06 \mathrm{~min}$, respectively. Retinyl propionate (internal standard for the quantification of retinol) had a retention time of $7.84 \mathrm{~min}$. Quantitation of retinoic acid was with external standards by comparison to a sevenpoint calibration curve using the area of the analyte response plotted against the amount of analyte injected. Retinal-oxime $\left(5 \mu \mathrm{L}, 16 \mathrm{ng} \mathrm{mL}{ }^{-1}\right.$ ) was injected post column as an external standard for the quantitation of $O$-ethyl oxime derivative after elution of the peak using a manual injector (Rheodyne, model MX7960-000, USA). Retinyl propionate $\left(10 \mu \mathrm{L}, 100 \mathrm{ng} \mathrm{mL}^{-1}\right)$ was added to extracts as an internal standard for the quantitation of retinol.
Quantitation of retinol and retinal-oxime was by comparison to a seven and eight-point calibration curve, respectively, using the ratio of the analyte response to the internal/ external standard plotted against the amount of analyte injected. The calibration curve used in all cases was weighted $(1 / x)$ second-order regression. The detection ranges used for the calibration curves were $25-800 \mathrm{ng} \mathrm{mL}^{-1}$ (retinol), 2-64 ng mL ${ }^{-1}$ (retinaldehyde) and 2-80 $\mathrm{ng} \mathrm{mL}^{-1}$ (retinoid acid). These ranges spanned the physiological range and in all cases $r>0.99$. The most abundant transition ion with the lowest accompanying background was selected for each analyte $(269 \rightarrow 95$ for retinol, $328 \rightarrow 236$ for retinal-oxime, and $301 \rightarrow 123$ for retinoid acid). Retinol, retinal-oxime and retinoic acid had a LOD of 2.10, 0.11 , and 0.17 pmol, respectively. Retinol, retinal-oxime, and retinoid acid had LOQs of 6.60, 0.36, and 0.53 pmol, respectively. All statistical analyses were evaluated at the $95 \%$ confidence level using SAS Software version 9.0 (SAS Institute Inc., Cary, NC, USA).

\section{Results and Discussion}

The analytical method used in the present study was sufficiently sensitive to quantitate physiological levels of the retinoids and comparable to methodology reported by van Breemen et al. (1998), Gundersen and Blomhoff (2001), McCoffery et al. (2002) Gundersen (2006), Gundersen et al. (2007), Kane et al. (2005, 2008a, b). The recovery of all three retinoid from testis rat at two different levels was greater than $98 \%$, with no greater than a $6 \%$ standard deviation from mean values, except for homogenate fortified with the lowest concentration of retinaldehyde (10 ng $\left.\mathrm{mL}^{-1}\right)$ where the standard deviation was $13 \%$ (Table 1). The recoveries for retinol and retinoic acid reported in the current study were similar to those reported by other researchers with different types of tissues (Kane et al. 2008a, b; Gundersen et al. 2007; Schmidt et al. 2003; Rühl 2006). For retinal-oxime, the recoveries were routinely slightly greater than $100 \%$, in agreement with the

Table 1 Recovery of retinoid from rat testis

\begin{tabular}{lll}
\hline Retinoid & $\begin{array}{l}\text { Added retinoid } \\
\left(\mathrm{ng} \mathrm{mL} \mathrm{mL}^{-1}\right)\end{array}$ & $\begin{array}{l}\text { Recovery } \pm \mathrm{SD} \\
(\mathrm{n}=7)\end{array}$ \\
\hline Retinol & 186 & $110 \pm 4.0$ \\
& 348 & $106 \pm 0.5$ \\
Retinaldehyde & 10 & $107 \pm 13.0$ \\
& 50 & $114 \pm 6.0$ \\
Retinoic acid & 20 & $98 \pm 6.0$ \\
& 70 & $103 \pm 6.0$ \\
\hline
\end{tabular}

Results are expressed as percent recovery \pm standard deviation 
results reported by Kane et al. (2008a). Comparison of percent recovery from rat testis homogenate with previous data is not possible as the majority of previous reports do not specify recovery from individual tissues (Kane et al. 2008a, b; Schmidt et al. 2003; Quadro et al. 1999). In the presence of sample matrix, retinoic acid demonstrated a lower signal (45\% less) due to ion suppression. The retinol and retinal-oxime did not show ion suppression effects. To overcome the matrix effect for retinoic acid, accurate quantitation of retinoic acid was achieved by the preparation of retinoic acid standard curves in negative control testis homogenate extract. Ion suppression associated with the presence of a matrix is an important factor in the analysis of retinoic acid (Gundersen 2006; Gundersen et al. 2007; Vogel et al. 2001). Previous reports by Schmidt et al. (2003) and Kane et al. (2005, 2008a, b) have quantified retinoids in testis. In the present study, retinol and retinoic acid were $226.0 \pm 19.00 \mathrm{pmol} \mathrm{g}^{-1}$ of tissue and
$9.5 \pm 1.00 \mathrm{pmol} \mathrm{g}^{-1}$ of tissue, respectively. These values were similar to those reported by Schmidt et al. (2003) $\left(334.0 \pm 0.03 \mathrm{pmol} \mathrm{g}^{-1}\right.$ of tissue, $12.7 \mathrm{pmol} \mathrm{g}^{-1}$ of tissue, respectively). Although many studies have tried to elucidate the mechanism by which molinate provokes testicular toxicity, to our knowledge this is the first report on effect of molinate on vitamin A homeostasis in rat testis. The vitamin A active metabolite retinoic acid is fundamental in spermatogenesis and promotes spermatogonia to enter the meiotic pathway by up-regulating the expression of Kit in germ cells while also increasing the expression of Kit ligand in Sertoli cells (Pellegrini et al. 2008). Retinoic acid appears to be responsible for the differentiation of undifferentiated spermatogonia, the initiation of the cycle of the seminiferous epithelium (Hogarth et al. 2010). The retinoic acid biosynthesis in testis occurs in Leydig and Sertoli cells. Sertoli cells are the main site of retinoic acid synthesis, in these cells the retinoic acid is delivered to germ
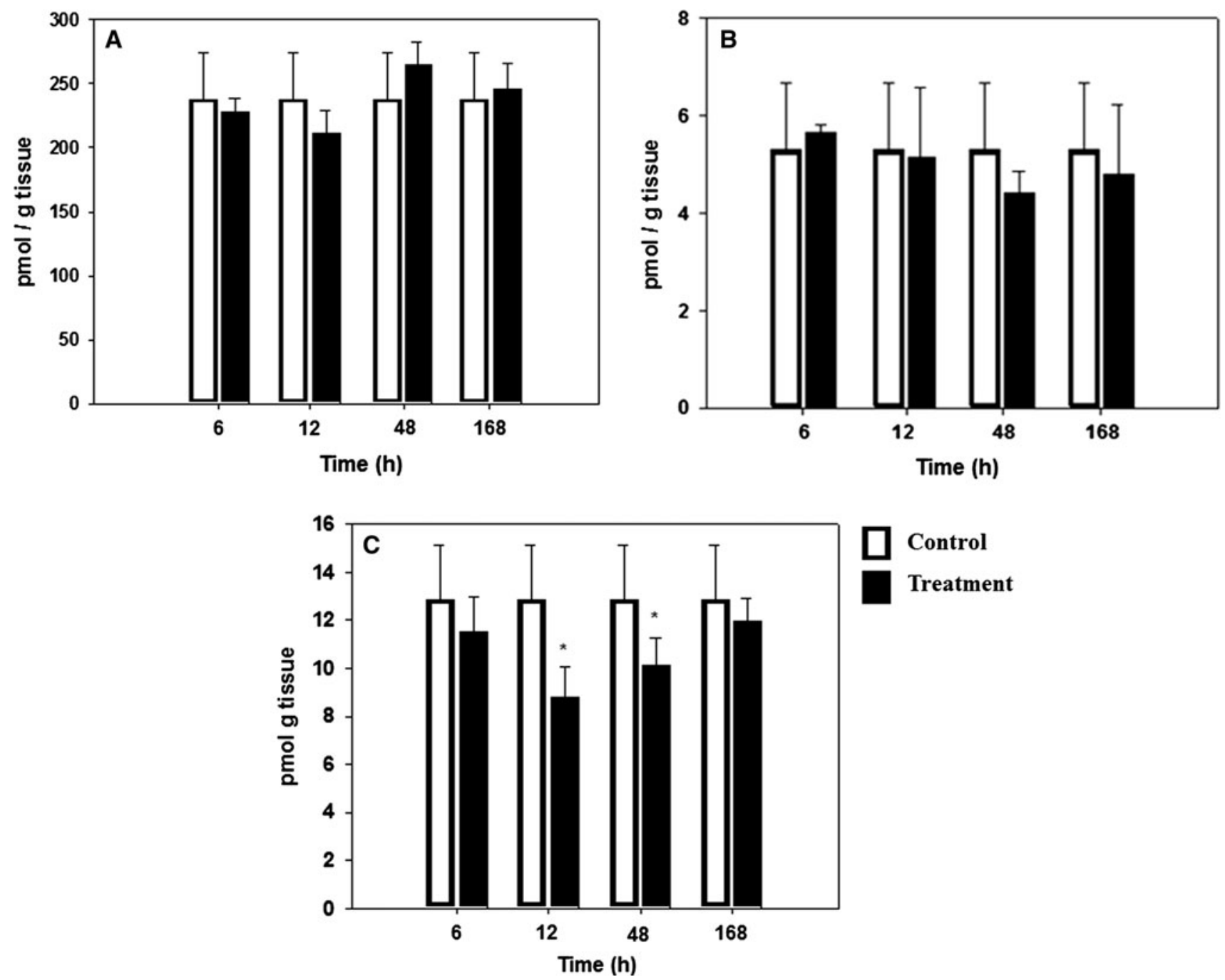

Fig. 1 The effect of molinate upon testis endogenous retinoid levels with time. Sexually mature male Sprague-Dawley rats (n = 4 per group) were administered a single dose of molinate $\left(200 \mathrm{mg} \mathrm{kg}^{-1}\right.$ ip). a Retinol; b Retinaldehyde; $\mathbf{c}$ Retinoic acid. Data is given as mean $\pm \mathrm{SD}$ 
cells (Livera et al. 2002; Cavazzini et al. 1996). Based on these reports, we conducted an in vivo study to elucidate the effect of molinate on vitamin A homeostasis in testis. Male Sprague-Dawley rats were treated with a single dose of molinate $\left(200 \mathrm{mg} \mathrm{kg}^{-1}\right.$ ip). Neither body nor testis weight were affected by molinate (data not shown). When endogenous retinoids were determined in testis from treated rats, levels of retinol and retinaldehyde were not affected, suggesting that molinate did not affect vitamin $\mathrm{A}$ metabolism via the conversion of retinol to retinaldehyde. However, retinoic acid levels were decreased at 12 and $48 \mathrm{~h}$ time points and a $32 \%$ inhibition of retinoic acid production was observed (Fig. 1). After $48 \mathrm{~h}$ post-exposure, a recovery of retinoic acid production was observed. At this time point, levels were similar to those observed with controls animals, indicating that molinate did affect the retinoic acid biosynthesis. A similar effect has been reported by several researchers in in vitro studies (Allen et al. 2010; Amory et al. 2011). The enzymes involved in retinoic acid biosynthesis in testis are retinalaldehyde dehydrogenase types 1 and 2 (RALDH1 and RALDH 2). RALDH 1 is more intensely expressed in spermatocytes, but much less expressed in spermatogonia and spermatids. RALDH 2 has been expressed in interstitial cells, spermatogonia and spermatocytes (Zhai et al. 2001). The role of RALDH 1 and RALDH 2 is decisive in the conversion of retinaldehyde to retinoic acid and they are reported to be responsible for retinoic acid synthesis in testis (Amory et al. 2011). Allen et al. (2010) have found that molinate sulfone modifies RALDH 2 through covalent binding, this reaction involves nucleophilic attack of the thiol to the carbonyl of molinate sulfone, resulting in the formation of a $126 \mathrm{Da}$ carbamete adduct. In the present study levels of retinaldehyde were also measured as a principal precursor of retinoic acid. According to the results, the levels of retinaldehyde were not affected by molinate. To elucidate the possible mechanism by which molinate could affect retinoic acid biosynthesis in testis, additional studies are necessary to measure the levels of retinal isoforms, acetaldehyde as well as other retinoic acid precursors.

Our data clear suggests that molinate suppress the retinoic acid biosynthesis. Furthermore the decrease in retinoic acid level may in turn be responsible for molinate induced testicular toxicity. The present research provides a basis for further studies, including studies with chronic exposure of molinate that will allow for elucidating the detailed mechanism by which molinate affects vitamin A homeostasis in testis.

Acknowledgments This study has been carried out with financial support from the National Institute of Environmental Health Science (NIEHS) Postdoctoral Training Grant T32E507059. The authors sincerely thank James Graham (Department of Nutrition, University of California-Davis) for providing animals used for method development. This paper is dedicated to the memory of Dr. Marion G. Miller.

Open Access This article is distributed under the terms of the Creative Commons Attribution License which permits any use, distribution, and reproduction in any medium, provided the original author(s) and the source are credited.

\section{References}

Allen EMG, Anderson DGR, Florang VR, Khanna M, Hurley DT, Doorn JA (2010) Relative inhibitory potency of molinate and metabolites with aldehyde dehydrogenase 2: implications for the mechanism of enzyme inhibition. Chem Res Toxicol 23: $1843-1850$

Amory JK, Muller CH, Shimshoni JA, Isoherranen N, Paik J, Moreb JS, Amory DW Sr, Evanoff R, Goldstein AS, Griswold MD (2011) Suppression of spermatogenesis by bisdichloroacetyldiamines is mediated by inhibition of testicular retinoic acid biosynthesis. J Androl 32:111-119

Barua AB, Furr HC (1998) Properties of retinoids: structure, handling and preparation. Mol Biotechnol 10:167-182

Cavazzini D, Galdieri M, Ottonello S (1996) Retinoic acid synthesis in the somatic cells of rat seminiferous tubules. Biochem Biophys Acta 1313:139-145

Chung SS, Wolgemuth DJ (2004) Role of retinoid signaling in the regulation of spermatogenesis. Cytogene Genome Res 105: 189-202

DeBau JR, Bova DL, Tseng CK, Menn JJ (1978) Metabolism of ${ }^{14} \mathrm{C}$ Ordram (molinate) in the rat. 2. Urinary metabolite identification. J Agri Food Chem 26:1096-1104

Ellis MK, Richardson AG, Foster JR, Smith FM, Widdowson PS, Farnworth MJ, Moore RB, Pitts MR, Wickramaratne GA (1998) The reproductive toxicity of molinate and metabolites to the male rat: effects on testosterone and sperm morphology. Toxicol Appl Pharmacol 151:22-32

Gaemers IC, van Pelt AMM, vander Saag PT, de Rooij DG (1996) All-trans-4-oxo-retinoic acid: a potent inducer of in vivo proliferation of growth-arrested A spermatogonia in the vitamin A-deficient mouse testis. Endocrinology 137:479-485

Gundersen TE (2006) Methods for detecting and identifying retinoids in tissue. J Neurobiol 66:631-644

Gundersen TE, Blomhoff R (2001) Qualitative and quantitative liquid chromatographic determination of natural retinoids in biological samples. J Chrom A 935:13-43

Gundersen TE, Bastani NE, Blomhoff R (2007) Quantitative highthroughput determination of endogenous retinoids in human plasma using triple-stage liquid chromatography/tandem mass spectrometry. Rapid Commun Mass Spectrom 21:1176-1186

Hart B, Faiman M (1995) Inhibition of rat liver low Km aldehyde dehydrogenase by thiocarbamate herbicides: occupational implications. Biochem Pharmacol 49:157-163

Hogarth C, Griswold MD (2010) The key role of vitamin A in spermatogenesis. J Clin Invest 120:956-962

Jewell WT, Miller MG (1998) Identification of a carboxylesterase as the major protein bound by molinate. Toxicol Appl Pharmacol 149:226-234

Jewell WT, Hess RA, Miller MG (1998) Testicular toxicity of molinate in the rat: metabolic activation by sulfoxidation. Toxicol Appl Pharmacol 149:159-166

Kane MA, Chen N, Sparks S, Napoli JL (2005) Quantification of endogenous retinoic acid in limited biological samples by LC/ MS/MS. J Biochem 388:363-369 
Kane MA, Folias AE, Napoli JL (2008a) HPLC/UV quantitation of retinal, retinol, and retinyl esters in serum and tissues. J Anal Biochem 378:71-79

Kane MA, Folias AE, Wang C, Napoli JL (2008b) Quantitative profiling on endogenous retinoic acid in vivo and in vitro by tandem mass spectrometry. J Anal Chem 80:1702-1708

Livera G, Rouiller-Fabre V, Pairault C, Levacher C, Habert R (2002) Regulation and perturbation of testicular functions by vitamin $\mathrm{A}$. Reprod 124:173-180

McCaffery P, Evans J, Koul O, Volpert A, Reid K, Ullman MD (2002) Retinoid quantification by HPLC/MS. J Lipid Res 43:1143-1149

Pellegrini M, Filipponi D, Gori M, Barrios F, Lolicato F, Grimaldi P, Rossi P, Jannini EA, Geremia R, Dolci S (2008) ATRA and KL promote differentiation toward the meiotic program of male germ cells. Cell Cycle 7:3878-3888

Quadro L, Blaner WS, Salchow DJ, Vogel S, Piantedosi R, Gouras P, Freeman S, Cosma MP, Colantuoni V, Gottesman ME (1999) Impaired retinal function and vitamin A availability in mice lacking retinol-binding protein. EMBO J 18:4633-4644

Rühl R (2006) Method to determine 4-oxo-retinoic acid, retinoic acids and retinol in serum and cell extracts by liquid chromatography/ diode-array detection atmospheric pressure chemical ionization tandem mass spectrometry. Rapid Commun Mass Spectrom 20:2497-2504

Schmidt CK, Brouwerb A, Nau H (2003) Chromatographic analysis of endogenous retinoids in tissues and serum. $\mathrm{J}$ Anal Biochem 315:36-48

van Breemen RB, Nikolic D, Xu X, Xiong Y, van Lieshout M, West CE, Schilling AB (1998) Development of a method for quantitation of retinol and retinyl palmitate in human serum using high-performance liquid chromatography-atmospheric pressure chemical ionization-mass spectrometry. J Chrom A 794:245-251

Vogel S, Mendelsohn CL, Mertz JR, Piantedosi R, Waldburger C, Gottesman ME, Blaner WS (2001) Characterization of a new member of the fatty acid-binding protein family that binds alltrans-retinol. J Biol Chem 276:1353-1360

Wilkes MF, Woollen BH, Marsh JR, Batten PL, Chester G (1993) Biological monitoring for pesticides exposure-the role of human volunteer studies. Int Arch Occup Environ Health 65:S189-S192

Zhai Y, Sperkova Z, Napoli JJ (2001) Cellular expression of retinal dehydrogenase types 1 and 2: effects of vitamin A status on testis mRNA. J Cell Physiol 186:220-232 